\title{
Analysis of job satisfaction of the nursing staff of a primary health care unit
}

\author{
Análise da satisfação profissional da equipe de enfermagem \\ em uma unidade básica distrital de saúde
}

RE Revista Gaúcha

Análisis de la satisfacción en el trabajo del personal

de enfermería en un distrito primaria de salud

\author{
lone Carvalho Pinto \\ Carla Santa Maria Marciliano Panobianco ${ }^{b}$ \\ Fabiana Costa Machado Zacharias ${ }^{b}$ \\ Alexandre Fávero Bulgarellic \\ Tânia Silva Gomes Carneiro ${ }^{d}$ \\ Mariana Figueiredo Souza Gomide \\ Ricardo Alexandre Arcênció ${ }^{f}$
}

\section{ABSTRACT}

This was a cross-sectional, observational study conducted in an outpatient specialty district health unit in the city of Ribeirão Preto, in the southeastern Brazilian state of São Paulo, with the aim to analyze the job satisfaction of the nursing staff. Data were collected using the Index of Work Satisfaction (IWS), a validated instrument which was applied to 23 members of the nursing team in January 2012. Among the components of job satisfaction, participants considered Interaction to be most important, followed by Professional Status, Job Requirements, Organizational Policies, Remuneration and Autonomy. The combined mean Index of Work Satisfaction obtained was 8.29, corresponding to poor job satisfaction among the studied population, as most of the studies in the literature that used the same instrument had scores between 12 and 37 .

Descriptors: Job satisfaction. Nursing team. Primary health care.

\section{RESUMO}

Estudo transversal com profissionais de enfermagem que objetivou analisar a satisfação profissional da equipe de enfermagem em um ambulatório de especialidades em Ribeirão Preto/SP. A coleta de dados foi realizada por meio da aplicação de um instrumento validado de Satisfação Profissional (ISP). Participaram do estudo 23 profissionais de enfermagem que compunham o quadro permanente de funcionários no mês de janeiro de 2012, período da coleta de dados. Dentre os atributos de satisfação avaliados, a equipe de enfermagem considerou o componente Interação como o mais importante, seguido do Status Profissional, Requisitos do Trabalho, Normas Organizacionais, Remuneração e Autonomia. Observou-se ainda, que o índice de Satisfação Profissional foi de 8,29, variando entre os participantes de 5,25 a 14,09, o que evidencia pouca satisfação do profissional de enfermagem com o trabalho, comparado com a literatura onde a maioria das pesquisas que utilizou este mesmo instrumento, o ISP situa-se entre 12 de um máximo de 37.

Descritores: Satisfação no emprego. Equipe de enfermagem. Atenção primária à saúde.

\section{RESUMEN}

Estudio observacional transversal realizado en un ambulatorio Especialidad Unidad de Salud del Distrito de la ciudad de Ribeirão Preto/SP, para analizar la satisfacción laboral del personal de enfermería. La recolección de datos se realizó a través del Índice de Satisfacción Profesional (ISP). Participaron del estudio 23 miembros del equipo de enfermería que trabajaban en enero de 2012, periodo de recolección de datos. Cuanto al nivel de importancia que se concede a los componentes de la satisfacción en el trabajo, se encontró que el personal de enfermería considera la interacción de componentes como el más importante, seguido por los componentes de estado-profesionales, requisitos laborales, estándares Organizacional, Compensación y Autonomía. También se observó que el valor del Índice de Satisfacción Profesional encontrado fue de 8,29 ISP a la clínica, que muestra la poca satisfacción en el entorno laboral, de esta populación en comparación con la literatura donde la mayoría de los estudios que utilizaron el mismo instrumento, presentó valores entre 12 hasta 37.

Descriptores: Satisfacción en el trabajo. Grupo de enfermería. Atención primaria de salud.
D0l: http://dx.doi.org/10.1590/19831447.2014.04.45491

\footnotetext{
Associate Professor. Ribeirão Preto College of Nursing, University of São Paulo. World Health Organization Collaborating Centre for Nursing Research Development, Brazil.

b Nurse. MSc, Ribeirão Preto College of Nursing, University of São Paulo. World Health Organization Collaborating Centre for Nursing Research Development, Brazil.

c Adjunct Professor. Faculty of Dentistry, Federal University of Rio Grande do Sul.

${ }^{d}$ Nurse. DSc, Ribeirão Preto College of Nursing, University of São Paulo. World Health Organization Collaborating Centre for Nursing Research Development, Brazil.

e Nurse. Doctoral student in Public Health, Ribeirão Preto College of Nursing, University of São Paulo. World Health Organization Collaborating Centre for Nursing Research Development, Brazil.

f Professor. Ribeirão Preto College of Nursing, University of São Paulo. World Health Organization Collaborating Centre for Nursing Research Development, Brazil.
} 


\section{口INTRODUCTION}

Throughout human history, work has become increasingly important for individuals and organizations. Today, work represents the determining factor in the degree of development of societies. This importance has become more evident after the socioeconomic changes that occurred mainly in the last two centuries following the Industrial Revolution ${ }^{(1)}$.

The definition of job satisfaction is not effortless. The literature on the subject is heterogeneous, with different explanations of the phenomenon ${ }^{(2)}$. In this heterogeneity there are controversies that hinder understanding the concept of job satisfaction, making it difficult to identify possible variables to explain it ${ }^{(3)}$. This study is based on the assumption that all concepts of satisfaction result from the rationale that it is imbued with emotions that individuals get from the work they perform ${ }^{(3)}$.

The appreciation of professionals as a fundamental tool in the work process has garnered interest, especially in institutions that care about workers' development and quality performance. By valuing human capital and recognizing the efforts of workers, healthcare organizations increase workers' productivity and job satisfaction(4).

Understandings of job satisfaction are derived from motivation, which is a concept that precedes satisfaction with regard to the motivational cycle. Motivation refers to the tension generated by a need, and satisfaction expresses the feeling of fulfilling this need ${ }^{(5)}$. It is necessary to identify the inner needs of the individual and the work conditions so that a professional feels accomplished at work, considering the individual's perception of reasonableness or fairness in their employment relationship with the organization ${ }^{(6)}$. The phenomenon of social comparison often occurs at work, focusing on the perception of each individual of the reasonableness or fairness of a work context, comparing their performance and benefits to the performance and benefits of others in identical situations ${ }^{(6)}$.

Job satisfaction studies with professionals employed in the Brazilian Unified Health System (SUS, as per its acronym in Portuguese) are still uncommon, although it is a topic relevant to public health and contributes to the realization of the ideal of health for all. Investments in human capital are increasingly valued in the context of healthcare institutions; therefore, studies on this topic are valuable for the development of these institutions. In the twenty-first century, human resources are one of the most important assets for the success of healthcare organizations and the SUS. Thus, the aim of this study was to analyze the job satisfaction of the nursing staff of a public health service, in a large city.

\section{METHODS}

This cross-sectional study was originated from a universal master's degree research project ${ }^{(2)}$ conducted with the nursing staff of a reference service for a population of 151,141 inhabitants. This service provides 24-hour urgency and emergency care, in addition to other clinical specialties. The healthcare unit is a reference to 17 primary healthcare units, including family health strategy (FHS) and basic health units.

The studied healthcare unit is in the city of Ribeirão Preto, which had 629,855 inhabitants in 2013, and attained a Human Development Index of 0.844, with an urbanization rate of $99.72 \%$ and aging index of $72.9 \%$. Compared to other cities in the state of São Paulo, Ribeirão Preto is in Group 2, according to State System Foundation for Data Analysis (SEADE). This category, which is one of five in the São Paulo Social Responsibility Index (IPRS), means that although Ribeirao Preto enjoys high levels of wealth, the city is lacking social indicators such as access to education and basic sanitation ${ }^{(7)}$.

The study population consisted of 23 nursing professionals that composed the personnel of the healthcare institution, regardless of the type of employment.

A purposeful sampling was defined for the research, selected from the population in a non-probabilistic manner, according to recommendations in the literature ${ }^{(8)}$. According to the authors, this is the best methodology, since the study is based on an exploratory approach and directed to a very specific and homogeneous population (nursing professionals).

Inclusion criteria were having worked at the unit for at least one year, willingness to participate in the interview, and not being on leave, vacation, off or away at the time of research. To characterize the study participants, the authors developed an instrument containing the variables sex, age, education level, type of employment relationship, number of weekly work hours and income. The Index of Work Satisfaction (IWS) was used to meet the research objectives. This is a self-administered instrument that has been adapted and validated in Brazil(9-10), and which employs the methodology of measuring subjects' attitudes towards work situations with a real level of job satisfaction, combining the measurement of work expectations, taking into account the importance attributed by the participants to satisfaction, autonomy, interaction, job requirements, organizational policies and remuneration ${ }^{(9-11)}$. 
The Index of Work Satisfaction weights the variables of the instrument domains, associating the importance attributed to each component of the job (autonomy, interaction, professional status, job requirements, organizational policies and remuneration) with the job satisfaction perceived by the nursing team ${ }^{(10-11)}$. Using a five-point response scale, the instrument was adapted and pretested on the study population of reference with nursing team professionals. These subjects were not included when the instrument was applied in the field. After pretesting and attainment of the list of research subjects provided by the personnel management of the healthcare unit, the instrument was distributed to the study participants at their workplace in January 2012. At this point, all subjects were contacted at the healthcare unit by one of the researchers, who explained the purpose of the study and instrument structure so that the participants were included successively in so far as they were willing to participate in the research and delivered the completed instruments.

Data were organized, categorized, coded and entered into an electronic spreadsheet in the Microsoft Office ${ }^{\oplus}$ Excel 2007 software, using the technique of independent double typing. They were then processed in the statistical program Statistical Analysis System ${ }^{\circledast}$ (SAS) version 9.1.

The response rates were converted into a ratio matrix (relative frequency) by dividing the absolute values (the number of times a response was provided divided by the size of the study population). The ratios were then converted into Matrix $Z$ standard deviations and the correction of $Z$ scores was used with a correction factor in order to avoid negative values. A value of +2.5 was sufficient to correct the values, differing from the procedure adopted in the original scale, which considered a factor of $+3.5^{(9-11)}$.

Cronbach's alpha coefficient, which is a statistical tool that quantifies the reliability of an instrument on a scale of 0 to 1 , was used to assess internal consistency.

The research proposal was approved by the Research Ethics Committee of the Ribeirão Preto College of Nursing, under protocol 287/09.12.2008, as per the Resolution 196/96 of the National Health Council. All subjects agreed to participate in the study by signing a free and informed consent form.

\section{RESULTS}

The study participants were 23 nursing professionals, whose socio-demographic characteristics are shown in Table 1. According to the table, 21 (91.30\%) of the participants were female, the majority were aged between 45 and $56(n=15 ; 65.22 \%)$, most had completed high school $(n=13 ; 56.52 \%)$ and were in the professional category of nursing aides ( $n=10 ; 43.48 \%$ ). The characteristics of the participants are presented in Table 1.

As for work hours, one nursing professional (4\%) worked 30 hours per week, one (4\%) worked 36 hours and 21 (92\%) worked 40 hours. Only two (9\%) had another job in the nursing area. As regards the hiring process, 12 (52\%) were contracted by public tender and 11 (48\%) by selective process and CLT regime.

Sixteen nurses (70\%) stated they had a fixed work schedule; that is, they worked in only one sector of the healthcare unit, whereas seven (30\%) covered more than one sector, performing varied activities as needed.

In terms of remuneration, one professional (4\%) reported that $s /$ he earned less than two minimum wages, five (23\%) earned between two and three minimum wages, six (26\%) between three and four minimum wages, three (13\%) between four and five minimum wages, six (26\%) between five and six minimum wages, one (4\%) between six and seven minimum wages, and one (4\%) earned more than seven minimum wages.

Table 1. Socio-demographic characteristics of the nursing team, according to workplace. Ribeirão Preto, 2012.

\begin{tabular}{lcc}
\multirow{2}{*}{ Variables } & \multicolumn{2}{c}{ Outpatient unit } \\
\cline { 2 - 3 } & (n) & $\%$ \\
Male & 2 & 8.70 \\
Female & 21 & 91.30
\end{tabular}

Age group

\begin{tabular}{lcc} 
25-34 years & 3 & 13.04 \\
35-44 years & 5 & 21.74 \\
45-56 years & 15 & 65.22 \\
Mean age(years) & 45 years & \\
Education level & & \\
Complete high school & 13 & 56.52 \\
Incomplete higher education & 4 & 17.39 \\
Complete higher education & 6 & 26.09 \\
Professional category & & \\
Nurse & 5 & 21.74 \\
Nursing technician & 8 & 34.78 \\
Nursing aide & 10 & 43.48 \\
\hline Total number of interviews & 23 & 100 \\
\hline
\end{tabular}

Source: research data. 
Table 2 shows the components that were most frequently selected by the study participants. The values in Table 2 were adjusted with the application of the factor +2.5 .

Diagram 1 shows the components that were most and least emphasized by the participants. The most important component to the subjects was Interaction, whereas Autonomy was the least important.
Table 3 shows the importance attributed by the Specialties Outpatient nursing team to components of job satisfaction, as well as the adjusted scores of the components, which is a weighted measurement between the level of importance the study participant attributed to the components, and his/her degree of satisfaction with the component in his/her workplace.

Table 2. Z-values matrix of the responses obtained in the paired comparisons from Part A of the Index of Work Satisfaction (IWS), showing the component weighting coefficient with the correction factor (+2.5). Ribeirão Preto, 2012.

\begin{tabular}{|c|c|c|c|c|c|c|c|}
\hline \multirow{2}{*}{\multicolumn{2}{|c|}{$\begin{array}{c}\text { Outpatient } \\
(n=23)\end{array}$}} & \multicolumn{6}{|c|}{ Most important } \\
\hline & & Remuneration & Autonomy & $\begin{array}{l}\text { Job re- } \\
\text { quirements }\end{array}$ & $\begin{array}{c}\text { Professional } \\
\text { status }\end{array}$ & $\begin{array}{c}\text { Organization- } \\
\text { al policies }\end{array}$ & Interaction \\
\hline \multirow{6}{*}{ 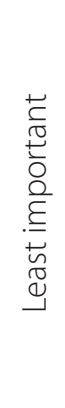 } & Remuneration & $-x-$ & 0.2078 & 0.4848 & 1.3159 & 0.4848 & 0.2078 \\
\hline & Autonomy & -0.2078 & $-x-$ & 0.2078 & 1.5929 & 0.3463 & 0.9003 \\
\hline & Job requirements & -0.4848 & -0.2078 & $-x-$ & 1.1774 & 0.2078 & 0.9003 \\
\hline & $\begin{array}{l}\text { Professional } \\
\text { status }\end{array}$ & -1.3159 & -1.5929 & -1.1774 & $-x^{-}$ & -1.5929 & 1.5929 \\
\hline & $\begin{array}{l}\text { Organizational } \\
\text { policies }\end{array}$ & -0.4848 & -0.3463 & -0.2078 & 1.5929 & $-x-$ & 1.1774 \\
\hline & Interaction & -0.2078 & -0.9003 & -0.9003 & -1.5929 & -1.1774 & $-x-$ \\
\hline \multicolumn{2}{|c|}{ Total } & -2.7010 & -2.8395 & -1.5929 & 4.0862 & -1.7314 & 4.7787 \\
\hline \multicolumn{2}{|c|}{ Mean } & -0.5402 & -0.5679 & -0.3186 & 0.8172 & -0.3463 & 0.9557 \\
\hline \multicolumn{2}{|c|}{ Correction factor } & 2.5 & 2.5 & 2.5 & 2.5 & 2.5 & 2.5 \\
\hline \multicolumn{2}{|c|}{ Weighting coefficient } & 1.96 & 1.93 & 2.18 & 3.32 & 2.15 & 3.46 \\
\hline
\end{tabular}

Source: research data.

\begin{tabular}{|c|c|c|c|c|c|}
\hline \multicolumn{7}{|c|}{ Outpatient nursing team } \\
\hline Most important \\
\cline { 2 - 6 } Interaction & $\begin{array}{c}\text { Professional } \\
\text { status }\end{array}$ & Job requirements & $\begin{array}{c}\text { Organizational } \\
\text { policies }\end{array}$ & Remuneration important & Autonomy \\
\hline
\end{tabular}

Diagram 1. Classification of components of the IWS by order of importance attributed to them by nursing professionals who participated in the study. Ribeirão Preto, 2012.

Source: research data.

\begin{tabular}{|c|c|c|c|c|c|}
\hline \multicolumn{9}{|c|}{ Outpatient nursing team } \\
More satisfied \\
\cline { 2 - 5 } Interaction & Autonomy & Remuneration & Job Requirements & $\begin{array}{c}\text { Organizational } \\
\text { policies }\end{array}$ & $\begin{array}{c}\text { Professional } \\
\text { status }\end{array}$ \\
\hline
\end{tabular}

Diagram 2. Classification of the IWS components by level of satisfaction of the nursing teams in the outpatient unit. Ribeirão Preto, 2012.

Source: research data. 
Pinto IC, Panobianco CSMM, Zacharias FCM, Bulgarelli AF, Carneiro TSG, Gomide MFS, et al.

Table 3. Numerical scores used to calculate the IWS and possible variations. Outpatient unit. Ribeirão Preto, 2012.

\begin{tabular}{lccc}
\multicolumn{1}{c}{ Component } & $\begin{array}{c}\text { I. Weighting coefficient } \\
\text { of the scale } \\
\text { Part A }\end{array}$ & $\begin{array}{c}\text { II. Mean score of the } \\
\text { scale component } \\
\text { Part B }\end{array}$ & $\begin{array}{c}\text { Ill. Adjusted component } \\
\text { score } \\
\text { Part A x B }\end{array}$ \\
\hline Autonomy & 3.46 & 3.55 & 12.27 \\
Interaction & 3.32 & 4.25 & 14.09 \\
Professional status & 218 & 2.41 & 5.25 \\
Job requirements*** & 2.15 & 2.83 & 6.10 \\
Organizational policies**** & 1.96 & 3.01 & 5.91 \\
Remuneration & 1.93 & 3.17 & 6.12 \\
\hline
\end{tabular}

Median score of the scale: 3.20 (variation from 1 to 5)

Index of Work Satisfaction: 8.29 (variation from 5.25 to 14)

Source: research data.

*after exclusion of items 20 and 30; **after exclusion of items 28 and 35; ***after exclusion of item 4; ****after exclusion of item 33

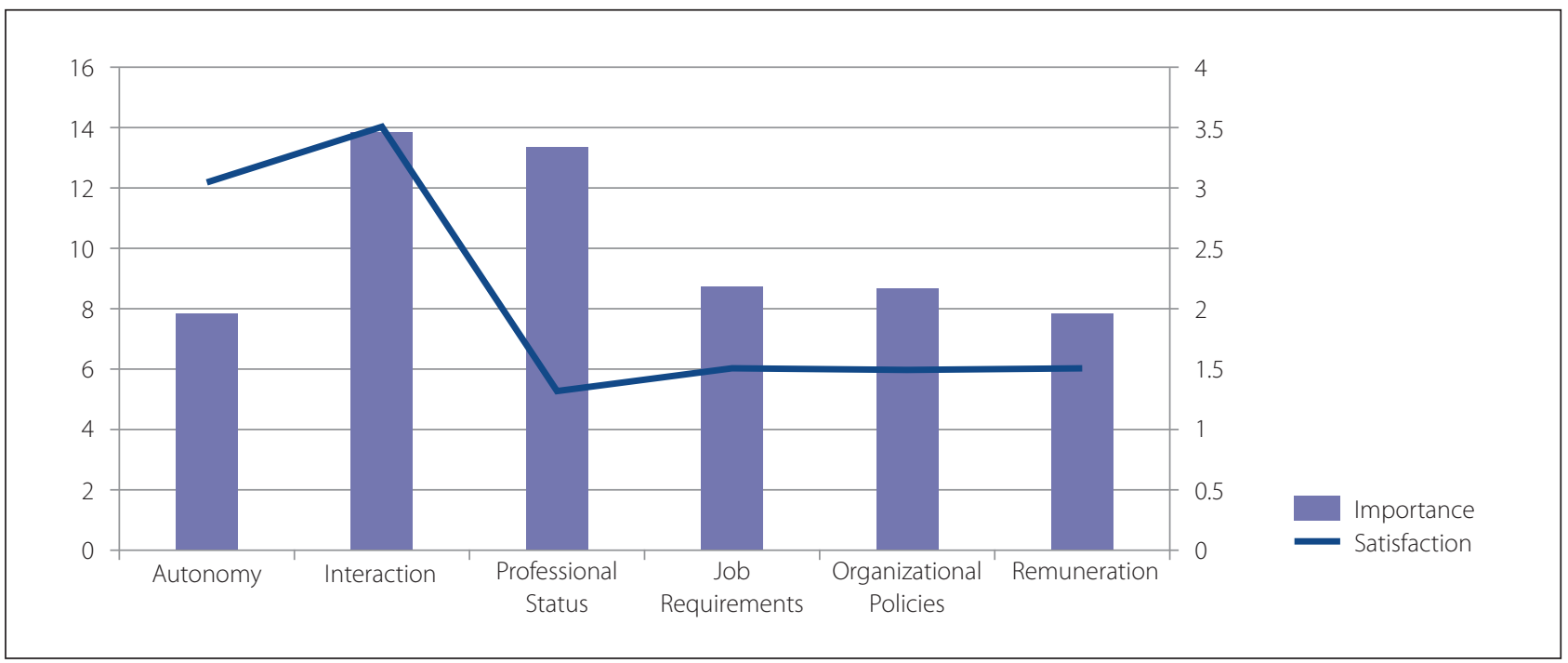

Figure 1. Representation of the IWS components by level of importance attributed to it and level of satisfaction identified, considering the variation limits of the scores in the outpatient unit. Ribeirão Preto, 2012.

Source: research data.

For better viewing, Diagram 2 shows the components that were classified according to the current level of job satisfaction of the nursing teams. It shows that interaction is an important component to participants, and that they are satisfied with it. Professional status is also important to the study subjects; however, it is also one of the components with which the participants are least satisfied. Organizational policies is another component with which participants are least satisfied.

The comparison of the hierarchical order of the components as regards levels of importance and satisfaction in Figure 1 shows some contradictions. For instance, autonomy is not recognized as being important to the study participants, but the team's satisfaction with this component is high. Interaction is one component valued by the participants, and with which they are satisfied. Although professional status is highly valued by the participants, it is the component with which participants are least satisfied. It is notable that for most of the components, there is a disparity in which the participants' satisfaction is greater than the importance they attribute to it. 
Cronbach's alpha coefficient indicated reliability of 0.78 , and the instrument was thus considered reliable.

\section{DISCUSSION}

This study sought to analyze the job satisfaction of the nursing team of a district primary healthcare unit. The results show that for the majority of the components of job satisfaction researched, satisfaction is lower than the level of expectation and importance attributed to it by subjects. While the study participants were satisfied with the component of professional interaction, they were least satisfied with professional status.

Autonomy was one of the least important components to the study participants, while interaction was the most important. Lack of autonomy is one of the primary reasons for dissatisfaction and increased stress among nursing professionals. ${ }^{(12)}$. Following autonomy, remuneration was not very important to the study subjects, who attributed less importance to this component than to interaction, professional status, job requirements and organizational policies.

As regards characteristics of the study participants, there was a predominance of females between the ages of 45 and 56, who had completed high school, corroborating the results in the literature ${ }^{(9-10)}$.

Double employment of workers was also observed, which may generate work overload, exhaustion and interfere in the quality and wellbeing of the professional and in job satisfaction. Increased workload may be associated with dissatisfaction among healthcare workers, mainly nursing staff ${ }^{(12)}$.

As regards remuneration, the study showed that the participants received a mean of four minimum wages, verifying that the remuneration conjuncture was also identified in other studies (10-11-13).

As regards the process of associations for comprehension of satisfaction with the work process experienced, the weighting coefficient enabled classification by order of importance of each of the IWS components. The weighting coefficient of the component both determines the IWS, and may be used to plan organizational actions, reference criteria for quality indicators, and in interventions by organizations aiming for job satisfaction among nursing teams ${ }^{(10)}$. This finding is similar to that of one study undertaken in a university hospital ${ }^{(14)}$, in which this component was the second most important for nurses, as well as the study performed in a Mobile Outpatient Emergency Service (SAMU, as per its acronym in Portuguese) ${ }^{(13)}$, in which it was classified as the third most important component for this service's nursing team.
The component professional status was classified as second most important for job satisfaction. This is in contrast to other studies, in which professional status was among the least important components of job satisfaction $^{(10,13-14)}$. The level of value placed on professional status is due to feelings generated among nursing professionals from devaluing and not recognizing nursing work, exemplified in low salaries, burden of responsibilities and low expectation for professional growth ${ }^{(13)}$. It is important to note that the classification exemplifies that the component remuneration is a factor of job dissatisfaction, but it is not the primary determinant of job satisfaction ${ }^{(10)}$.

The component autonomy had a mean score of 3.55, interaction 4.25, professional status 2.41 , job requirements 2.83, organizational policies 3.01 and remuneration 3.17. The sum of the mean scores of the components divided by six (total number of components) generated the overall mean score of the IWS scale ${ }^{(15-16)}$, shown at the end of Table 3. The overall mean score for the nursing staff from the Specialties Outpatient Unit that participated in the study was 3.2. In comparison, one study undertaken in the city of Sao Paulo ${ }^{(12)}$ had a mean score of 3.4, whereas another one in the city of Natal ${ }^{(13)}$ had a mean score of 3.5 , with possible variation from 1 to 7 .

The component autonomy had an adjusted score of 12.27, whereas for interaction this score was 14.09, professional status 5.25, job requirements 6.10 , organizational policies 5.91 and remuneration 6.12. Interpretation of the adjusted component scores enabled identification of the teams' perception of their job satisfaction, and therefore classification of the components from most satisfying to least satisfying.

As regards the real level of job satisfaction, calculated by means of the sum of the adjusted component scores, there was a variation among the participants from 5.25 to 14.09. Most studies that used this same instrument (the IWS) had real levels of job satisfaction ranging from 12 to a maximum of $37^{(15)}$. Based on the above, the job satisfaction of the individuals of both nursing teams is low. Thus, in general, nursing teams in Brazil are dissatisfied at work.

One study on job satisfaction among nurses in an intensive care unit had an IWS of 9.53. One study reports an IWS score of 8.6 for the nursing team from a SAMU (Portuguese acronym for Mobile Emergency Medical Service) ${ }^{(13)}$. The highest IWS score found in the literature was $12.08^{(3)}$.

In this study, interaction was the job component perceived as having the greatest influence on job satisfaction; that is, it was the component with which the participants were most satisfied. Alternatively, professional status was the component with which the study participants were 
least satisfied (Diagram 2). In one quasi-experimental study, nurses were least satisfied with the components organizational policies, job requirements and professional status, a result very similar to that found in this study ${ }^{(17)}$. The authors of that study concluded that the nurses' needs were more focused on the organization and management of the service. These needs reflect the importance of careful management and organization of nursing work so that higher levels of job satisfaction in this field are attained. Respect and communication within the nursing team increase the level of job satisfaction among its members ${ }^{(18)}$. Good relationships among the nursing team are pointed to in the literature as increasing pleasure in the workplace and therefore job satisfaction ${ }^{(19)}$.

The study participants' need to establish, disclose and fulfill the policies and standards that guide the institution and healthcare service shows that although flexibility should be present throughout the chain of management, standardization and disciplinary actions need to be implemented ${ }^{(17,19)}$.

The low scores of the component job requirements can also be attributed to a possible negative influence of the component organizational policies, one of the components with the lowest levels of satisfaction for both nursing teams studied.

Autonomy and interaction were components for which the perceived level of satisfaction was equal to or greater than the attributed level of importance. This is important because although autonomy was classified lowest in terms of attributed level of importance, it was the component with which the participants were most satisfied. The component professional status had the greatest discrepancy between attributed level of importance and level of satisfaction. Professional status, while a determinant of job satisfaction for the study participants, is related to recognition and respect for these professionals' work among their peers, physicians, patients, families, managers and other professionals of the healthcare team. The desire to be understood, appreciated and recognized is the driving force of human behavior ${ }^{(19)}$. In this study, professional status is very important for the healthcare service, yet the team is dissatisfied in this regard. The basic driving force of human behavior is the desire to be understood, appreciated and recognized at work ${ }^{(20)}$. It is believed that the more an organization is capable of creating an environment that conduces creativity, the more efficient it becomes, just like leaders that awaken and encourage enthusiasm, liberate groups from unjustifiable procedures with low social impact, please creative people, look to the future and promote innovation, nursing professionals are infused with new incentive and enthusiasm to face the challenges of healthcare production that is more equitable, just and capable of transforming a social reality.

Based on the evidence presented above, investments in human resources, on the part of managers, are needed so as to encourage professional development, reorganization of organizational policies and the mobilization of nursing professionals in order to obtain improvements in healthcare practices that embody comprehensiveness and humanization of care.

\section{口 CONCLUSION}

The results found in the analysis of the reliability of the IWS by means of Cronbach's al pha coefficient demonstrated that it is a reliable instrument to measure job satisfaction levels of the nursing team in the reality of a healthcare service.

As regards the level of importance attributed to the components of job satisfaction, the studied nursing team considers interaction to be the most important. In terms of level of satisfaction regarding the components of job satisfaction, the nursing team was most satisfied with interaction. The low scores of the job satisfaction index of the study participants, who had a combined mean score of 8.29 and whose individual scores varied from 5.25 to 14.09 , may compromise the performance of healthcare practice and the quality of the care provided.

This study addresses important aspects of job satisfaction of the primary care nursing team, yet further studies are crucial in order to understand the complexity and determinants of job satisfaction amongst SUS workers. There is no doubt that more satisfied and motivated workers will result in greater impacts on health care.

It is believed that understanding the job satisfaction of the nursing staff through the components autonomy, interaction, professional status, job requirements, remuneration and organizational policies can help strengthen the SUS. This fact also enriches the reorientation of health and nursing care practices, to the extent that workers may express their potentialities and difficulties at work.

Thus, there is evidence for the organizational logic of health care and the human resources policy, allowing changes to difficult situations identified by the highest and lowest levels of job satisfaction that teams develop in their work in healthcare services.

\section{口EFERENCES}

1. Andrade LMC. A satisfação profissional nos enfermeiros de pediatria [dissertação]. Porto: Faculdade de Medicina, Universidade do Porto; 2001. 
2. Marciliano CSM. Análise da satisfação profissional da equipe de enfermagem em uma unidade básica distrital de saúde de Ribeirão Preto-SP [dissertação]. Ribeirão Preto (SP). Escola de Enfermagem de Ribeirão Preto, Universidade de São Paulo; 2012.

3. Matsuda LM. Satisfação profissional da equipe de enfermagem de uma UTI adulto: perspectiva de gestão para a qualidade da assistência [tese]. Ribeirão Preto (SP): Escola de Enfermagem de Ribeirão Preto, Universidade São Paulo; 2002.

4. Santos MCL, Braga VAB, Fernandes AFC. Nível de satisfação dos enfermeiros com seu trabalho. Rev Enferm UERJ. 2007 jan-mar;15(1):82-6.

5. Steuer RS. Satisfação no trabalho, conflito e ambiguidade de papéis: estudo junto às enfermeiras da Maternidade Escola do Município de São Paulo [dissertação]. Faculdade de Saúde Pública, Universidade de São Paulo;1989.

6. Ferreira VLA. Satisfação profissional dos enfermeiros em cuidados de saúde primários no distrito de Braga [dissertação] Porto: Faculdade de Economia, Universidade do Porto; 2011.

7. Assembleia Legislativa do Estado de São Paulo [Internet]. São Paulo: SEAD; 2012- [atualizado 2012 out 22, citado 2014 out 22]. IPRS versão 2012: Índice Paulista de Responsabilidade Social 2012. Disponível em: http://www.iprsipvs. seade.gov.br/view/index.php?selLoc=0\&selTpLoc $=2 \& p r o d C o d=1$

8. Daniel J. Sampling essentials: practical guidelines for making sampling choices, Washington: SAGE Publications; 2012.

9. Lino MM. Satisfação profissional entre enfermeiros de UTI: adaptação transcultural do Index of Work Satisfaction (IWS) [dissertação]. São Paulo (SP). Escola de Enfermagem, Universidade de São Paulo;1999.

10. Lino MM. Qualidade de vida e satisfação profissional de enfermeiras de unidades de terapia intensiva [tese]. São Paulo (SP): Escola de Enfermagem, Universidade de São Paulo; 2004.
11. Slavitt DB, Stamps PL, Piedmont EB. Nurses satisfaction with their work situation. Nurs Res. 1978;27(2):114-20.

12. Pires DEP, Bertoncini JH, Trindade LL, Matos E, Azambuja E, Borges AMF. Inovação tecnológica e cargas de trabalho dos profissionais de saúde: uma relação ambígua. Rev Gaúcha Enferm. 2012 mar;33(1):157-68.

13. Campos RM. Satisfação da equipe de enfermagem do serviço de atendimento móvel às urgências (SAMU) no ambiente de trabalho [dissertação]. Natal (RN): Escola de Enfermagem, Universidade Federal do Rio Grande do Norte; 2005.

14. Silva RM. Satisfação profissional dos enfermeiros de um holWStal universitário o trabalho noturno [dissertação]. Santa Maria(RS): Centro de Ciências da Saúde, Universidade Federal de Santa Maria; 2008.

15. Stamps PL. Scoring workbook for the index of work satisfaction. 2nd ed. Northampton: Market Research; 1997.

16. Shimazaki K, Tsubakita T. Measurement of job satisfaction in nursing school teachers: confirmatory factor analysis of a job satisfaction scale based on the Stamps Scale. Int J Nurs Science. 2013;3(1):7-14.

17. Matsuda LM, Évora YDM. Gestão da equipe de enfermagem de uma UTI: a satisfação profissional em foco. Cienc Cuid Saúde. 2003 jan-mar;2(1):11-8.

18. Feather, R. A., Ebright, P. and Bakas, T. Nurse manager behaviors that RNs perceive to affect their job satisfaction. Nurs Forum. 2014. Epub 2014 Jan 16. doi:10.1111/nuf.12086

19. Kessler Al, Krug SBF. Do prazer ao sofrimento no trabalho da enfermagem: 0 discurso dos trabalhadores. Rev Gaúcha Enferm. 2012 mar;33(1):49-55.

20. Underwood J, Carter L. 0 princípio da significância: o segredo por trás do alto desempenho de pessoas e organizações. Campinas (SP): United Press; 2000.

\section{Author's address:}

Ione Carvalho Pinto

Av. Bandeirantes, 3900, Vila Monte Alegre

14040-902, Ribeirão Preto, SP

E-mail: ionecarv@eerp.usp.br
Received: 09.03.2014

Approved: 10.11.2014 